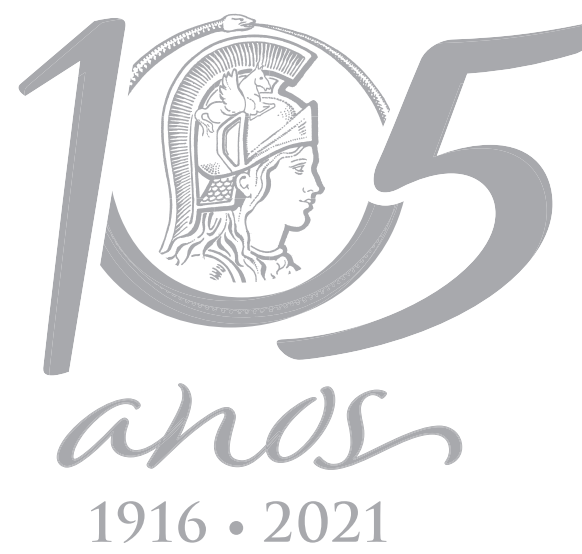

\title{
Differential defense responses of tropical grasses to Mahanarva spectabilis (Hemiptera: Cercopidae) infestation
}

\author{
RAFAEL DE A. BARROS, CAMILO E. VITAL, NEILIER R.S. JÚNIOR, MANUEL A.S. \\ VARGAS, LUANA P. MONTEIRO, VERÔNICA A. FAUSTINO, ALEXANDER M. AUAD, \\ JORGE F. PEREIRA, EUGÊNIO E. DE OLIVEIRA, HUMBERTO J.O. RAMOS \& MARIA \\ GORETI A. OLIVEIRA
}

\begin{abstract}
The spittlebugs Mahanarva spectabilis economically challenges cattle production of neotropical regions, due to its voracious feeding on tropical grasses. Here, we evaluated biochemical responses of the interaction between M. spectabilis and the widely cultivated tropical grasses Brachiaria spp. (i.e., brizantha and decumbens) and elephant grasses (cvs. Roxo de Botucatu and Pioneiro), regarding lipoxygenases, protease inhibitors, phytohormones, and proteolytic activities in the midgut of $M$. spectabilis. The M. spectabilis-infested grasses increased lipoxygenases activity, except for cv. Pioneiro. The levels of the phytohormones jasmonic and abscisic acids were similarly low in all genotypes and increased under herbivory. Furthermore, salicylic acid concentration was constitutively higher in Brachiaria sp., increasing only in spittlebuginfested B. decumbens. M. spectabilis infestations did not induce increases of protease inhibitors in any forage grass type. The trypsin activity remained unaltered, and the total proteolytic activity increased only in $B$. decumbens-fed insects. Our findings revealed that most forage grasses exposed to spittlebugs activate the lipoxygenases pathway, resulting in increased abscisic and jasmonic acids. However, greater amounts of these hormones do not induce protease inhibitory activity in response to spittlebug attack. This knowledge certainly helps to guide future projects aiming at reducing the impact of spittlebugs on forage production.
\end{abstract}

Key words: Hormones, insect, midgut, protease, stress.

\section{INTRODUCTION}

The most common system for animal production in Brazil is the pasture-based system. For that end, around 100 million hectares of planted pasture are used to feed more than 200 million cattle heads (Pereira et al. 2018). Even so, the estimated carrying capacity is 274-293 million animal units and, to achieve this greater capacity, the pasture productivity should be higher (Strassburg et al. 2014). Spittlebugs infestation is among the main biotic stresses faced by forage grasses in Brazil, reducing pasture productivity and causing major economic impacts (Valério et al. 2001). Among the species of spittlebugs, Mahanarva spectabilis (Hemiptera: Cercopidae) is found in a large area of the Brazilian territory, infesting several forage grasses and composing the main insect pests damaging elephant grasses (Silva et al. 2017, Machado et al. 2012). The more severe damage is caused by adult spittlebugs injuries, reducing photosynthetic capacity, thus, decreasing forage production and quality (Aguiar et al. 2014, Resende et al. 2013, Souza et al. 2008). 
The use of insecticides to control spittlebugs in the field is not economically viable and, even if it was, its undesirable effects on human health and insecticide resistance should be considered (Leite et al. 2014). For instance, up to date, 31 hemipterans have shown resistance to at least one pesticide (Whalon et al. 2019). Thus, the most effective, economic and environmentfriendly way to control spittlebugs is the natural genetic resistance.

In general, plant resistance against insects includes two types of defences: constitutive (i.e., physical barriers and proteins/metabolites that already exist in the plant before the insect attack) and inducible defenses (i.e., activation of protection mechanisms upon the insect attack) (Chen 2008). The inducible defense depends on different steps, including hormonemediated signaling that regulates several pathways (Schuman \& Baldwin 2016). The phytohormonal crosstalk among abscisic acid (ABA), jasmonic acid (JA) and salicylic acid (SA) play an important role in the plant responses to stress (Nguyen et al. 2016). The attack of herbivores activates the lipoxygenase pathway in plants, increasing the concentration of JA, a phytohormone that regulates defense-related genes expression (Meriño-Cabrera et al. 2018, Paixão et al. 2013). Lipoxygenases are enzymes that catalyze the deoxygenation of linoleic acid, producing intermediates used by the octadecanoid pathway to produce JA (Farmer \& Ryan 1992). Commonly, one of the downstream consequences of higher JA concentration is the activation of genes expressing protease inhibitors (Shivaji et al. 2010). Protease inhibitors are small proteins with a major role as defensive proteins against herbivores, being induced by plants under exposure to sap-feeding insects (Akbar et al. 2018, Voelckel et al. 2004). When ingested by the insect, the protease inhibitors bind tightly to the active site of proteases in the insect gut, forming an essentially irreversible complex (Akbar et al. 2018). Since proteases from the insect gut are essential for the digestion of proteins, the intake of protease inhibitors by herbivores affects protein degradation, reducing the availability of amino acids required for their development, growth, and reproduction (Oliveira et al. 2005). In contrast, insects respond to proteolytic impairment by increasing the production and secretion of proteases in their midgut, in an attempt to overcome the inhibitory effect (Oliveira et al. 2013). The elephant grass (Cenchrus purpureus syn. Pennisetum purpureum) cultivars Pioneiro and Roxo de Botucatu and Brachiaria decumbens (syn. Urochloa decumbens) cultivar Basilisk and Brachiaria brizantha (syn. Urochloa brizantha) cultivar Marandu are widely cultivated among the neotropical region due to their capacity of forming high quality pasture. These cultivars present different levels of resistance against $M$. spectabilis nymphs, being the cvs. Pioneiro and Marandu classified as resistant and cvs. Roxo de Botucatu and Basilisk as susceptible (Auad et al. 2007, Miles et al. 2006). The cvs. Pioneiro and Marandu resistance to $M$. spectabilis is conferred by antibiosis since the insects present diminished survival when feeding on these plants (Auad et al. 2007, Silva et al. 2017). However, the differential biochemical responses displayed by these cultivars under M. spectabilis herbivory that could be mediating resistance are not known.

The lack of knowledge regarding the biochemical interaction of the herbivoreplant interaction prevents further progress in the development of novel resistant cultivars (War et al. 2012). Thus, investigating the specific changes in the interaction of $M$. spectabilis and forage grasses is necessary to understand the mechanisms involved in the defense against this important pest. Here, we 
reported the biochemical changes of different forage grasses under M. spectabilis herbivory, regarding lipoxygenases activity, phytohormone levels, and protease inhibitors. Furthermore, we assessed the activities of total proteases and trypsin-like enzymes in the midgut of the insect.

\section{MATERIALS AND METHODS}

\section{Plants and insects}

The vegetative propagules (10-cm single node) of elephantgrass (Cenchrus purpureus syn. Pennisetum purpureum) cultivars Pioneiro and Roxo de Botucatu were collected from the experimental field of Embrapa Gado de Leite (Embrapa Dairy Cattle, lat 21033'18" S, long 43이두" W, at $417 \mathrm{~m}$ ). Seeds of Brachiaria decumbens (syn. Urochloa decumbens) cultivar Basilisk and Brachiaria brizantha (syn. Urochloa brizantha) cultivar Marandu were sown in trays with 200 cells and cultivated for 7-10 days. In fact, Brachiaria spp. is easily propagated by seeds, while elephant grass is not. Elephant grass produces very few seeds with a low germination rate; thus, it is commonly vegetatively propagated. The seedlings and the vegetative propagules were transplanted into pots $(1 \mathrm{~L})$ containing soil mixture and commercial substrate Plantmax ${ }^{\oplus}$ (1:1; v/v). The soil mixture was fertilized with $50 \mathrm{~mL}$ of urea solution $\left(8 \mathrm{~g} . \mathrm{L}^{-1}\right)$ at 25 days after transplanting and approximately 15 days later the plants were selected for the experiments. The plants were maintained in a greenhouse and irrigated daily until the trial was set up.

Fourth and fifth instar M. spectabilis nymphs were collected in pastures from the experimental field of Embrapa Gado de Leite (described above) and transported to the Laboratory of Insects at the Department of Biochemistry and Molecular Biology at the Federal University of Viçosa (UFV). The nymphs were kept in Brachiaria ruzizienses cultivar Kennedy that is highly susceptible to M. spectabilis (Alvarenga et al. 2017). The plants were wrapped to prevent insects from escaping using an organza bag $(40 \times 60 \mathrm{~cm})$ and incubated at $25{ }^{\circ} \mathrm{C}$ and $70 \%$ relative humidity, until the appearance of adults. Once the insect became adults, only the most vigorous individuals and that had no visual symptoms of parasitism, were selected and used in further experiments.

\section{Infestation of Mahanarva spectabilis}

The experiments were conducted in the Laboratory of Insects at the Department of Biochemistry and Molecular Biology at the Federal University of Viçosa (UFV) at $25 \pm 2$ ${ }^{\circ} \mathrm{C}, 70 \pm 10 \%$ relative humidity and under $12-\mathrm{h}$ light:12-h dark photoperiod. Four biological replicates per treatment were placed in a $2 \times 4$ factorial scheme, with two levels of the factor infestation (presence or not of M. spectabilis) and four levels of the factor cultivar (cv. Pioneiro and cv. Roxo de Botucatu of elephantgrass, cv. Basilisk of $B$. decumbens and $\mathrm{cv}$. Marandú of $B$. brizantha). Each plant was completely wrapped using an organza bag $(40 \times 60 \mathrm{~cm})$ to avoid the insects from escaping and infested with fifteen adults of $M$. spectabilis, 40 days after transplanting. The insects and four leaves of the plants (covering the lower, middle and upper part of the plants) were collected after 48 hours, frozen with liquid nitrogen and stored at -80 oC for further analysis.

\section{Determination of lipoxygenases activity and protease inhibitors}

The leaves were weighed, pulverized with liquid nitrogen and macerated. The powder was homogenized with $50 \mathrm{mM}$ sodium phosphate buffer, pH 6.5 and $0.1 \mathrm{M}$ Tris- $\mathrm{HCl}$ buffer $\mathrm{pH} 8.2$ containing $20 \mathrm{mM} \mathrm{CaCl}_{2}$ in the ratio of $1 \mathrm{~g}$ of leaf per $3 \mathrm{~mL}$ of buffer. The extract was centrifuged at $17,200 \mathrm{~g}$ for $30 \mathrm{~min}$ at $4{ }^{\circ} \mathrm{C}$ (Meriño-Cabrera 
et al. 2018). The supernatant was used for the protease inhibitors and lipoxygenases activity assays.

The lipoxygenase activity on linoleic acid was measured by the formation of the conjugated double-bond system of hydroperoxide which can be detected at $234 \mathrm{~nm}$. The reaction mixture consisted of $10 \mu \mathrm{L}$ of the supernatant (plant extract), $20 \mu \mathrm{L}$ of $10 \mathrm{mM}$ sodium linoleate and $1000 \mu \mathrm{L}$ of $50 \mathrm{mM}$ sodium phosphate buffer, $\mathrm{pH}$ 6.5. After 2 min, the activity was measured at 234 $\mathrm{nm}$. The speed of the reaction was measured using the molar extinction coefficient of 25.000 $\mathrm{M}^{-1} \mathrm{~cm}^{-1}$ (Axelrod et al. 1981).

The protease inhibitors were determined by measuring the inhibition of purified trypsin when mixed with the supernatant (plant extract) and using L-BApNA as substrate. The absorbance (410 $\mathrm{nm}$ ) was measured after $2.5 \mathrm{~min}$. The analyses were performed in triplicate for each biological replicate. The results were converted to $\mathrm{mg}$ of trypsin inhibited per gram of protein, according to the equation $A \times B /(C \times 1000 \times P)$, where: $A$ is the absorbance at $410 \mathrm{~nm}$ of the control; $B$ is the sample dilution; $\mathrm{P}$ is the protein concentration of the plant extracts (g. $\mathrm{mL}^{-1}$ ); and $\mathrm{C}$ is the trypsin factor, i.e., the product of the action of $1 \mu \mathrm{g}$ of active trypsin using L-BApNA as substrate will result in absorbance of 0.019 at $410 \mathrm{~nm}$ (Kakade et al. 1974). The protein concentration from leaves was determined using bovine serum albumin (BSA) as standard and the analyses were performed at $595 \mathrm{~nm}$ (Bradford 1976).

\section{Quantification of phytohormones}

The hormones were extracted from the leaves according to Müller and Munné-Bosch with modifications (Müller \& Munn-Bosch 2011). Approximately $110 \mathrm{mg}$ of the frozen tissue was powdered in liquid nitrogen and $400 \mu \mathrm{L}$ of extraction solvents (methanol: isopropyl alcohol: acetic acid, 20:79:1) were added. The samples were mixed in a vortex (4 times for 20 seconds), sonicated (5 minutes), kept in ice (30 minutes) and centrifuged $\left(13,000 \mathrm{~g}, 10\right.$ minutes in $\left.4^{\circ} \mathrm{C}\right)$. After centrifugation, $350 \mu \mathrm{L}$ of supernatant was transferred to a new tube. The process was repeated with the pellet, and the supernatants were then put together. A final centrifugation step (20000 g, 10 minutes in $4^{\circ} \mathrm{C}$ ) was performed to remove the rest of tissue in suspension.

The sample was automatically injected $(5 \mu \mathrm{L})$ in the system LC - MS/MS using an Agilent 1200 Infinity Series coupled to a mass spectrometry type triple quadrupole (QqQ), model 6430 Agilent Technologies. Chromatographic separation was carried out on a column Zorbax Eclipe Plus C18 $(1.8 \mu \mathrm{m}, 2.1 \times 50 \mathrm{~mm})$ (Agilent) in series with a guard column Zorbax SB- C18, $1.8 \mu \mathrm{m}$ (Agilent). The solvent used was: (A) acetic acid $0.02 \%$ in water and (B) acetic acid $0.02 \%$ in acetonitrile in a gradient of time per $\%$ of $B$ as: $0 / 5 ; 11 / 60$; $13 / 95 ; 17 / 95 ; 19 / 5 ; 20 / 5$. The solvent flow rate was $0.3 \mathrm{~mL}$. $\mathrm{min}^{-1}$ in a column temperature of $30{ }^{\circ} \mathrm{C}$. The ionization method used in the mass spectrometry was an ESI (Electrospray Ionization) in the following conditions: gas temperature of $300{ }^{\circ} \mathrm{C}$, nitrogen flow rate of $10 \mathrm{~L}$. $\mathrm{min}^{-1}$, nebulizer pressure of 35 psi and capillary voltage of 4000 V.

The equipment was operated on mode MRM (multiple reaction monitoring). The mass of the precursor ion/fragment was monitored by fragmentation tests of each molecule: abscisic acid - ABA (263/153), jasmonic acid - JA (209/59) and salicylic acid - SA (137/93). ABA, JA and SA were scanned in the negative mode. A calibration curve (0.1 ng a $400 \mathrm{ng}$ ) using the respective standards of each hormone was generated to determine the absolute quantification. The data were analyzed using the software Skyline to obtain the peak areas for each hormone in the sample, and the results were expressed in $\mathrm{ng} / \mathrm{g}$ of fresh tissue. 


\section{Determination of trypsin-like and total proteolytic activities in $M$. spectabilis midgut}

The insects used for determination of trypsinlike and total proteolytic activities were those used for infestation of plants. Males and females of $M$. spectabilis were placed separately and, the abdomen region was extracted and mixed in four individuals from each sex using a scalpel. The abdomens were macerated with liquid nitrogen and homogenized in $800 \mu \mathrm{L}$ of $\mathrm{HCl} 10^{-3} \mathrm{M}\left(4^{\circ} \mathrm{C}\right)$. The fractions were centrifuged at $10,000 \mathrm{~g}$ in three cycles of $20 \mathrm{~min}$ at $4^{\circ} \mathrm{C}$ and the supernatant was collected and used to measure the total proteolytic and trypsin-like enzymatic activities. The protein concentration from midguts was performed as described above for the leaves (Bradford 1976).

The total proteolytic activity was determined using $2 \%(\mathrm{w} / \mathrm{v})$ azocasein as substrate in $0.1 \mathrm{M}$ Tris- $\mathrm{HCl}$ buffer, $\mathrm{pH} 8.2$ containing $20 \mathrm{mM} \mathrm{CaCl}_{2}$, at $37^{\circ} \mathrm{C}$. The reaction mixture consisted of 70 $\mu \mathrm{L}$ of substrate and $80 \mu \mathrm{L}$ of enzyme extract (supernatant containing the enzymatic pool of M. spectabilis midgut). The reaction was stopped by adding $240 \mu \mathrm{L}$ of $10 \%(\mathrm{w} / \mathrm{v}$ ) trichloroacetic acid. The samples were then homogenized in a vortex, kept on ice for $15 \mathrm{~min}$ and centrifuged at $10,000 \mathrm{~g}$ for $5 \mathrm{~min}$ at $25^{\circ} \mathrm{C}$ to remove the precipitated protein. An aliquot of $240 \mu \mathrm{L}$ of the supernatant was transferred to microtubes containing $280 \mu \mathrm{L}$ of $1 \mathrm{M} \mathrm{NaOH}$. The final total proteolytic activity was measured at $440 \mathrm{~nm}$. The specific activity was determined by dividing the absorbance values to the total protein concentration (Tomarelli 1949).

The trypsin-like activity was determined using L-BApNA as the substrate where a $60 \mathrm{mM}$ stock solution was prepared, using $0.026 \mathrm{~g}$ of L-BApNA in $1 \mathrm{~mL}$ of DMSO (Dimethyl sulfoxide). The stock solution $(200 \mu \mathrm{L})$ was used to prepare a $1.2 \mathrm{mM}$ solution, through the dilution in $10 \mathrm{~mL}$ of $0.1 \mathrm{M}$ Tris- $\mathrm{HCl}$ buffer, $\mathrm{pH} 8.2$ with $20 \mathrm{mM} \mathrm{CaCl}_{2}$ at $25^{\circ} \mathrm{C}$. The reaction mixture was composed of $300 \mu \mathrm{L}$ of substrate, $300 \mu \mathrm{L}$ of buffer and $100 \mu \mathrm{L}$ of the enzymatic extract (supernatant containing the enzymatic pool of $M$. spectabilis midgut). The initial velocity of the reaction was determined by the formation of the $p$-nitroanilide product at $410 \mathrm{~nm}$ after 2 minutes. The calculations were performed with the molar extinction coefficient of $8,800\left(\mathrm{M}^{-1} \times \mathrm{cm}^{-1}\right)$ for the product (Erlanger et al. 1961).

\section{Statistical analyses}

Data from lipoxygenases activity, protease inhibitors and phytohormones were subjected to a nested ANOVA (Supplementary Material - Table SI) with cultivar within species. Furthermore, the data were subject to a two-way ANOVA and the means compared using the Tukey's test at $5 \%$ significance. One-way ANOVA followed by the Tukey's test was used to analyze data of the total proteolytic activity and the trypsin-like. The software used was SIGMAPLOT 12.0.

\section{RESULTS}

\section{Lipoxygenases activity in leaves of forage grasses when attacked or not by $M$. spectabilis}

The difference in the meanvalues oflipoxygenases among the different levels of cultivar $\left(F_{3,31}=3.7\right.$; $P=0.026)$ and infestation $\left(F_{1,31}=31.3 ; P<0.001\right)$ were statistically different. Besides that, the effect of different levels of cultivar did not depend on what level of infestation is present $\left(F_{3,31}=0.9\right.$; $P=0.477)$. The leaves of Roxo de Botucatu, $B$. brizantha and $B$. decumbens showed increased lipoxygenases activity after being exposed to $M$. spectabilis. Furthermore, the leaves of Pioneiro showed higher lipoxygenases activity than Roxo de Botucatu when not infested by M. spectabilis, showing varied basal activity for this enzyme between cultivars of elephant grasses. The same responsive pattern observed for the other 
cultivars can be noticed for Pioneiro, although spittlebugs injury did not induce significant lipoxygenase increases (Figure 1).

\section{Changes in concentration of phytohormones under M. spectablis infestation}

The difference in the mean values of jasmonic and abscisic acids among the different levels of cultivar, infestation and their interaction were statistically different. However, the difference in the mean values of salicylic acid were only statistically significant among cultivar levels (Table I). The concentration of abscisic acid (ABA) and jasmonic acid (JA) increased in all forage grass cultivars exposed to $M$. spectabilis infestation when compared with their noninfested controls. However, the increase in the levels of JA due to herbivory was lower in the leaves of the Roxo de Botucatu than the other cultivars. The concentrations of abscisic and jasmonic acids were similar among all noninfested forage grasses (Figure 2a, 2b). Regarding salicylic acid (SA), the basal concentration of this hormone (e.g., non-infested plants) was pronouncedly higher for the two Brachiaria species, showing greater concentrations than elephant grasses' cultivars (Table SI). The salicylic acid concentration only increased after herbivory in the leaves of $B$. decumbens plants (Figure 2c).

\section{Protease inhibitors after M. spectabilis infestation}

The difference in the mean values of protease inhibitors differed among the different levels of the cultivar factor $\left(F_{3,31}=18.967 ; P<0.001\right)$. The activity of protease inhibitors did not increase when the plants were infested by $M$. spectabilis. However, the basal concentration of protease inhibitors was higher in the leaves of Brachiaria species than in elephant grass cultivars (Table SI, Figure 3).

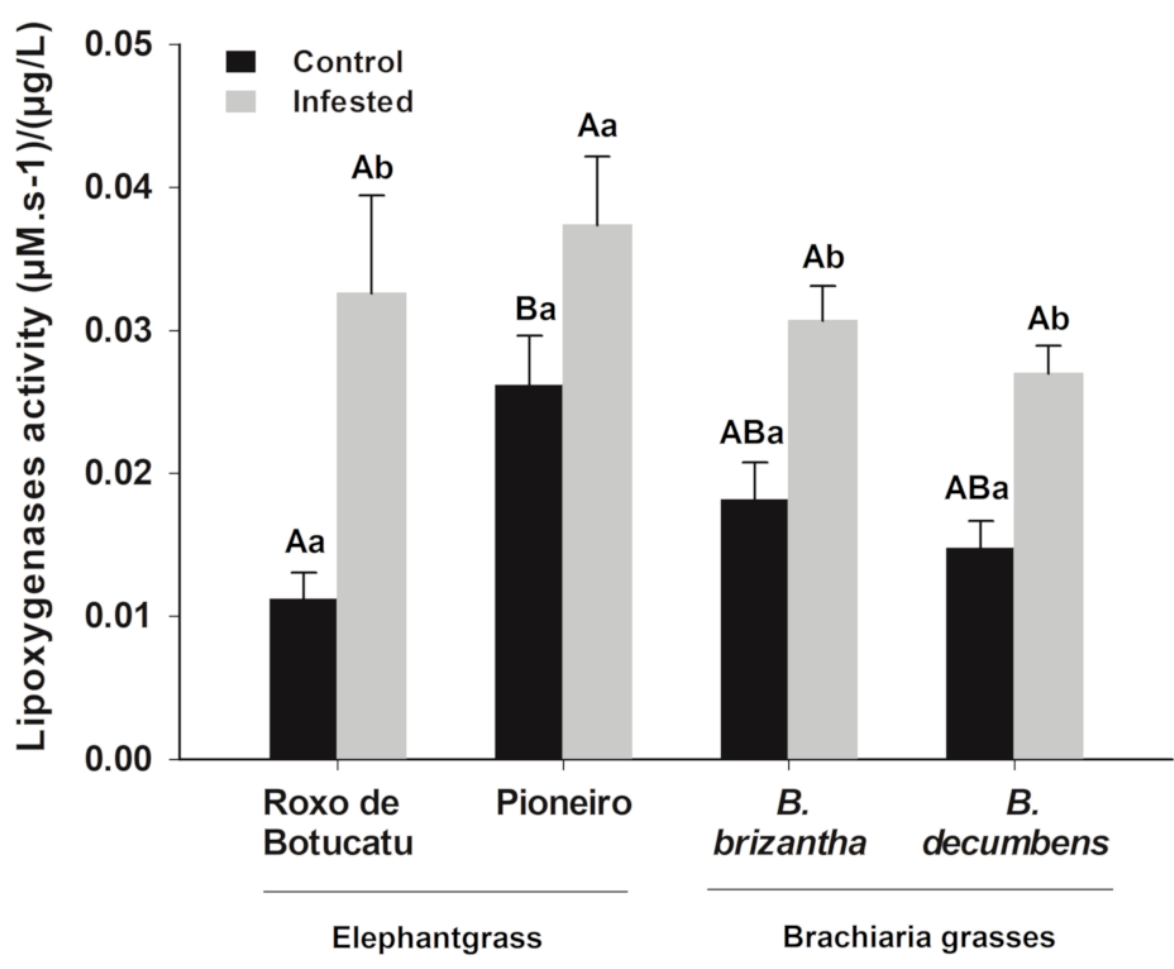

Figure 1. Lipoxygenase activities in leaves of different forage grasses (cvs. Roxo de Botucatu and Pioneiro of elephant grass, B. brizantha, and B. decumbens) infested or not (control) with Mahanarva spectabilis. Bars (mean \pm $\mathrm{SE} ; \mathrm{n}=4$ ) with the same lowercase letters indicate no significant difference between control and infested treatments and those followed by the same capital letters indicate no significant difference among forage grasses within the same treatment (Tukey's test: $P<0.05)$. 
Table I. Two-way anova parameters for phytohormes of forage grasses exposed to M. spectabilis herbivory.

\begin{tabular}{|c|c|c|c|c|}
\hline Phytohormone & Source of variation & D.F. & $\boldsymbol{F}$ & P-value \\
\hline Jasmonic Acid & Cultivar & 3 & 5.666 & 0.004 \\
\hline Abscisic Acid & Infestation & 1 & 102.871 & $<0.001$ \\
\hline Salicylic Acid & Cultivar x Infestation & 3 & 5.674 & 0.004 \\
\hline & Cultivar & 3 & 19.026 & $<0.001$ \\
\hline & Infestation & 1 & 159.211 & $<0.001$ \\
\hline & Cultivar x Infestation & 3 & 19.657 & $<0.001$ \\
\hline & Cultivar & 3 & 45.497 & $<0.001$ \\
\hline & Infestation & 1 & 3.625 & 0.069 \\
\hline
\end{tabular}

\section{Proteolytic activity in the midgut of $M$. spectabilis}

The activities of total proteases and trypsin-like were analyzed in the midgut of $M$. spectabilis adults fed on the forage grasses. The trypsinlike activity in the midgut of the insects fed on each of the four forage grasses cultivars showed similar activities $\left(F_{4,15}=0.953 ; P=0.446\right)$, whereas the activity of total proteases was significantly higher when the insects fed on $B$. decumbens $\left(F_{4}\right.$, ${ }_{15}=9.744 ; P=0.002$ ) (Figure 4).

\section{DISCUSSION}

We were interested in shedding some light on the biochemical interaction of spittlebugs and tropical forage grasses. This work is the first one to characterize the lipoxygenase activity, phytohormones, and protein inhibitors in different species of tropical forage grasses when infested by $M$. spectabilis. It is also the first report about the protease activity in the $M$. spectabilis midgut. We believe this knowledge is important to guide future progress in increasing the genetic resistance of forage grasses against this key pest.

The increase in lipoxygenase activity after exposure to $M$. spectabilis indicates that this enzyme has a role at the defense mechanism of the cultivars Roxo de Botucatu (elephant grass), Marandu (B. brizantha) and Basilisk (B. decumbens). Lipoxygenase activity induction by herbivory is often reported for other plant interactions with sucking-sap insects such as soybean and tobacco after infestation by Euchistos heros (Hemiptera: Pentatomidae) and Myzus nicotianae (Hemiptera: Aphididae), respectively (Timbó et al. 2014, Voelckel et al. 2004). The accumulation of jasmonic acid (JA) in the leaves of Roxo de Botucatu, B. brizantha, and $B$. decumbens is related to the increased lipoxygenase activities after the spittlebugs attack. Lipoxygenases enzymes oxidize the linoleic acid released by plants after recognizing molecular patterns associated with herbivory, providing intermediates for the production of JA (Roach et al. 2015). Even if the lipoxygenases activity were not significantly higher than noninfested plants in the Pioneiro, this inducible mechanism is probably also present in this cultivar since it is highly conserved on plants under herbivory. However, other precursors and routes can be responsible for increasing the concentration of this hormone (Wasternack \& Hause 2013). The possible supply of precursors for the production of jasmonic acid by different 

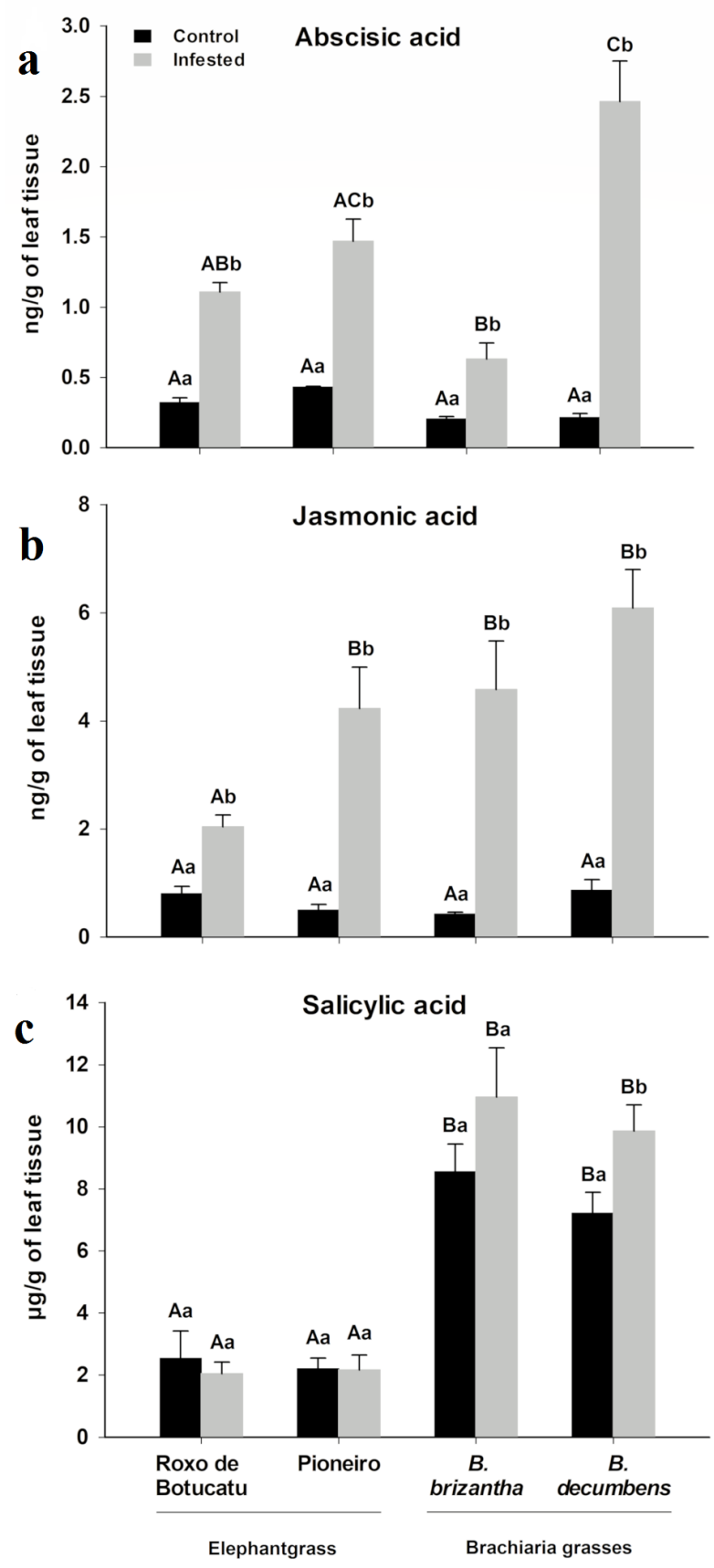

Figure 2. Concentrations of abscisic acid (a), jasmonic acid (b) and salicylic acid (c) in leaves of different forage grasses (cvs. Roxo de Botucatu and Pioneiro of elephant grass, B. brizantha, and B. decumbens) infested or not (control) with Mahanarva spectabilis. Bars (mean $\pm S E ; n=4$ ) with the same lowercase letters indicate no significant difference between control and infested treatments and those followed by the same capital letters indicate no significant difference among forage grasses within same treatment (Tukey's test: $P$ $<0.05$ ). routes may be an unlikely explanation for the non-significant difference in the increase in lipoxygenase activity after herbivory, but an important observation for future work regarding Pioneiro cultivar. The sucking-sap insect Nilapavarta lugens also induced JA concentration and lipoxygenases activity on rice plants after herbivory, showing a similar mirrored pattern to that observed here (Zhou et al. 2014). It has also been shown that increased lipoxygenases gene transcription is related to JA accumulation in stressed tomato plants (Yan et al. 2013).

Our results also showed that injury by $M$. spectabilis led to the lowest concentration of JA in CV. Roxo de Botucatu being this concentration less than half of the cv. Pioneiro. This information is important because these cultivars belong to the same species (Cenchrus purpureus syn. Pennisetum purpureum) and have different levels of antibiosis resistance against nymphs of M. spectabilis (Machado et al. 2012, Auad et al. 2007). The lower capacity of cv. Roxo de Botucatu in producing JA after injury may be used as a guide to help explain its greater susceptibility to $M$. spectabilis nymphs in comparison to cV. Pioneiro. The downregulation of lipoxygenase genes in barley plants decreased the expression of JA-dependent genes, reducing the resistance against the aphid Rhopalosiphum padi L. (Losvik et al. 2017a). Although it still to be proven if the different levels of resistant to nymphs are also applied for M. spectacbilis adults. The correlation between nymph survival and adults was very low for other spittlebugs species infesting Brachiaria spp., suggesting that the resistance to different life stages is independent (Cardona et al. 2010).

In addition to the biosynthesis of JA, the levels of abscisic acid (ABA) were increased in all forages after injury. Thus, ABA is also associated with the response of the forages 


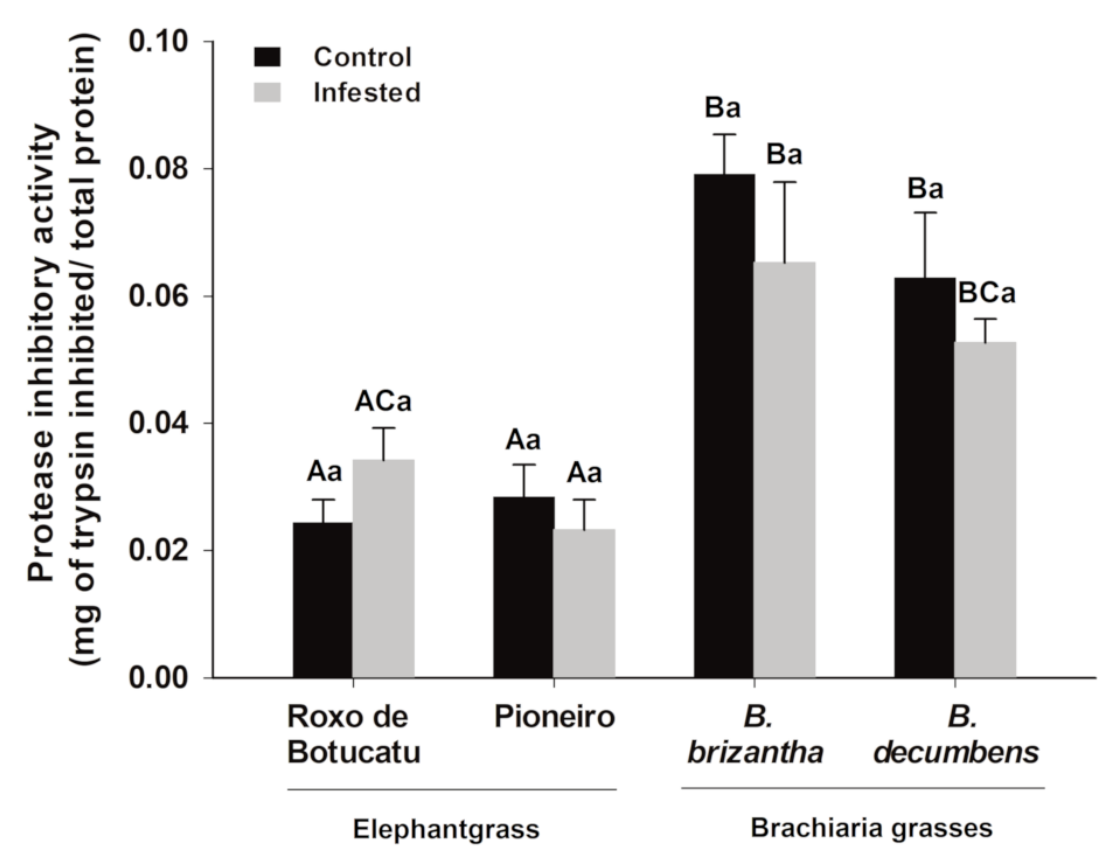

Figure 3. Protease inhibitory activity in leaves of different forage grasses (cvs. Roxo de Botucatu and Pioneiro of elephant grass, B. brizantha, and $B$. decumbens) infested or not (control) with Mahanarva spectabilis. Bars (mean $\pm \mathrm{SE} ; \mathrm{n}=4$ ) with the same lowercase letters indicate no significant difference between the control of infested treatments. Those followed by the same capital letters indicate no significant difference among forage of grasses within same treatment (Tukey's test: $P<0.05$ ). to the attack of $M$. spectabilis. The increase in ABA levels is possibly due to the need to boost defenses against the spittlebugs since, for other species, ABA and JA act synergistically in the expression of transcription factors that regulate the expression of anti-herbivory related genes ${ }^{38-40}$. Besides JA and ABA, the signaling response through salicylic acid (SA) usually plays a role in resistance to insects, increasing the expression of genes encoding compounds involved in defense, such as chitinases and pathogenesisrelated proteins (Hoysted et al. 2017, Smith \& Boyko 2007). Interestingly, in the current study, SA was not induced after injury in Cv. Roxo de Botucatu, cv. Pioneiro and B. brizantha. This could be related to effector proteins present in the M. spectabilis saliva that could avoid the induction of the SA signaling response as already demonstrated for other insects, such as aphids (Giordanengo et al. 2010). More experiments are needed to better explain non-induction of SA in most tropical forages analysed. However, the constitutive higher levels of SA in the two species of Brachiaria may be related to the defense against this insect pest. It has been shown that higher constitutive levels of SA are important for the soybean genotype KS4202 in the tolerance mechanism against the soybean aphid, Aphis glycines (Chapman et al. 2018). Besides controlling the expression of defense compounds, SA itself might harm insect pest. For example, aphids feeding an artificial diet enriched with SA had lower levels of survival than those fed with control diet (Donovan et al. 2013). The cultivar B. decumbens was the only that showed a significant increase in SA levels, and the signaled response mediated by this hormone could be one of the reasons why adults of $M$. spectabilis feature lower longevity and oviposition in this plant (Silva et al. 2017). Rice plants also showed increased SA concentration in the leaves after being injured by the planthopper Sogatella furcifera (Hemiptera: Delphacidae) (Kanno et al. 2012). An increase in the levels of reactive oxygen species, such as superoxides and hydrogen peroxide, usually precedes salicylic acid biosynthesis in plants (O'Brien et al. 2012). Reactive oxygen species can also cause negative effects on the midgut of arthropods (Smith \& Boyko 2007). 

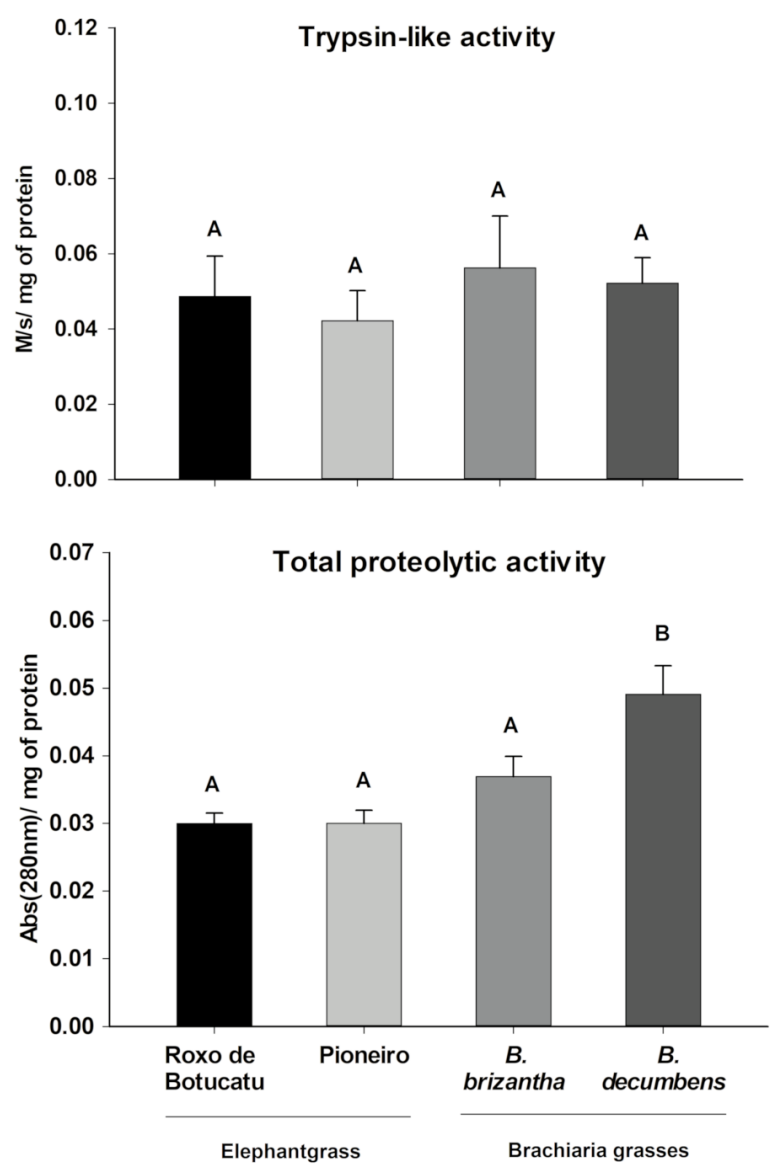

Figure 4. Trypsin-like activity and total proteolytic activity analyzed in the midgut of Mahanarva spectabilis adults fed on different forage grasses (cvs. Roxo de Botucatu and Pioneiro of elephant grass, $B$. brizantha and, B. decumbens). Bars (mean $\pm S E ; n=4$ ) with the same letters indicate no significant difference between treatments (Tukey's test: $P<0.05$ ).

However, the increase in the biosynthesis of SA after the injury should be better studied in forages to understand its anti-insect effects against $M$. spectabilis, since SA is also related to the decrease of secondary metabolites in these plants, such as phenolic compounds (Auad \& Resende 2018).

The induction of JA concentration after herbivory is usually correlated with increased expression of genes encoding protease inhibitors and other defensive proteins (Farmer \& Ryan et al. 1992). Protease inhibitors may reduce the performance of herbivores causing deficiency of free amino acids due to reduced proteolytic activity or increased protease secretion to compensate for the activity of inhibited enzymes (Oliveira et al. 2013, Paixão et al. 2013, 2016). Despite all the forages had increased levels of JA after the M. spectabilis injury none had induction of proteinase inhibitory activity, indicating that another signal is required to induce these molecules in forage grasses. Besides that, insect-derived effectors probably present in the salivary glands of $M$. spectabilis could also be downregulating protease inhibitors in the forage grasses (Felton et al. 2014).

The higher protease inhibitory activities observed in B. brizantha and B. decumbens did not cause a lower activity of protease in the midgut of spittlebugs. Indeed, proteinase inhibitors have not been usually considered to be an effective defense response against phloemfeeding insects, as they have been frequently reported to be rendered ineffective since insect pests develop alternative digestive strategies quickly after exposure to these molecules (Singh et al. 2020). However, it was observed increased proteolytic activity in the midgut of M. spectabilis fed with $B$. decumbens, indicating secretion of digestive proteases, as a way to overcome protease inhibition. Plant defense products that cause decrease in the proteolytic activity may indirectly affect the development of the herbivore, increasing the production of digestive enzymes in an attempt to compensate for those inhibited (Paixão et al. 2016, Oliveira et al. 2013). The secretion of enzymes to hold proteolytic activity at normal levels after exposure to compounds with inhibitory activity is a common mechanism in herbivores. For example, Spodoptera frugiperda larvae showed increased transcription of protease genes when fed with a diet containing the Entada acaciifolia trypsin inhibitor (EATI) (Oliveira et al. 2013). 
The greater total proteolytic activity in $M$. spectabilis fed with $B$. decumbens indicates that other defense metabolites may also affect digestive proteases or that $B$. decumbens has different types of protease inhibitors with higher efficiency (War et al. 2013, Fiorentino et al. 2007). In addition to protease inhibitors, other secondary plant metabolites, such as caffeic acid, negatively affected the proteolytic activity of Helicoverpa armigera (Lepidoptera: Noctuidae) midgut (Joshi et al. 2014). Moreover, the trypsin-like activities were similar among M. spectabilis fed with the four forage grasses genotypes, indicating that the change in total protease is not related to this class of enzymes.

The search for elephant grass and Brachiaria spp. genotypes showing induction of protease inhibitors after spittlebugs herbivory would be interesting, enabling the introduction of this characteristic in commercial cultivars through conventional breeding or transgenic approaches. Although the use of protease inhibitors against sap feeding hemipteran pests has received limited attention it has been shown that transgenic Arabidopsis thaliana plants expressing a protease inhibitor from barley resulted in lower fecundity of the generalist green peach aphid (Losvik et al. 2017b, Chougule \& Bonning 2012). In this way, the lack of induction of protease inhibitors in forage grasses upon the attack of $M$. spectabilis may be seen as an opportunity and not as an obstacle.

Although not addressed in detail here, it is relevant to note that plants can elicit different lipoxygenase (e.g., 9-LOX and 13LOX) pathways, known to produce particular sets of metabolites, including volatiles, and to activate independent downstream signaling or biosynthetic pathways, each with unique properties (Zhou et al. 2014). Further experiments using genomic or transcriptomic approaches will contribute to identifying plant processes (other than the accumulation of phytohormones and lipoxygenase pathways) that are relevant in the interactions between plants and phytosuccivorous insect pests.

In conclusion, we presented new insights regarding the biochemical interaction between tropical forage grasses and $M$. spectabilis, highlighting the absence of an important plant defense mechanism against herbivores. The absence of protease inhibitors induction in response to $M$. spectabilis might be a target for plant breeders to work on. Furthermore, an analysis of a greater number of forage grasses accessions might indicate if the changes in phytohormone levels can be used as indicators of the resistance level against spittlebugs. We understand that this knowledge is important to guide efforts in increasing the genetic resistance of forages against this major pest, M. spectabilis.

\section{Acknowledgments}

This study was supported by Instituto Nacional de Ciência e Tecnologia em Interações Planta-Praga (INCTIPP), Núcleo de Análises de Biomoléculas (NuBioMol, UFV), Empresa Brasileira de Pesquisa Agropecuária (EMBRAPA), Fundação de Amparo à Pesquisa de Minas Gerais (FAPEMIG), Coordenação de Aperfeiçoamento de Pessoal de Nivel Superior (CAPES) - Finance Code 001 and Conselho Nacional de Desenvolvimento Científico e Tecnológico (CNPq).

\section{REFERENCES}

AGUIAR DDM, AUAD AM, FONSECA MDG \& LEITE MV. 2014. Brachiaria ruziziensis responses to different fertilization doses and to the attack of Mahanarva spectabilis (Hemiptera: Cercopidae) nymphs and adults. The Sci W J 2014: 543813.

AKBAR SMD, JABA J, REGODE V, KUMAR GS \& SHARMA HC. 2018. Plant protease inhibitors and their interactions with insect gut proteinases. The biology of plantinsect interactions - A compendium for the plant biotechnologist, ed. By Emani C CRC Press: Boca Raton, p. 1-47. 
ALVARENGA R, AUAD AM, MORAES JC, SILVA SE, RODRIGUES BS \& SILVA GB. 2017. Spittlebugs (Hemiptera: Cercopidae) and their host plants: a strategy for pasture diversification. Appl Entomol and Zool 52: 653-660.

AUAD AM \& RESENDE TT. 2018. Use of chemical inducers as a resistance trigger in Brachiaria grasses and sugarcane. Fla Entomol 101: 119-125.

AUAD AM, SIMÕES AD, PEREIRA AV, BRAGA ALF, SOUZA SOBRINHO F, LÉDO FJS, PAULA-MORAES SV, OLIVEIRA AS \& FERREIRA RB. 2007. Seleção de genótipos de capim-elefante quanto à resistência à cigarrinha-das-pastagens. Pesq Agropec Bras 42: 1077-1081.

AXELROD B, CHEESBROUGH TM \& LAAKSO S. 1981. Lipoxygenase from soybeans: EC 1.13. 11.12 Linoleate: oxygen oxidoreductase. In: Lowenstein JM (Ed). Methods in enzymology. New York: Academic Press, p. 441-451.

BRADFORD MM. 1976. A rapid and sensitive method for the quantitation of microgram quantities of protein utilizing the principle of protein-dye binding. Anal Biochem 72: 248-254.

CARDONA C, MILES JW, ZUÑIGA E \& SOTELO G. 2010. Independence of resistance in Brachiaria spp. to nymphs or to adult spittlebugs (Hemiptera: Cercopidae): implications for breeding for resistance. J Econ Entomol 103: $1860-1865$.

CHAPMAN KM, MARCHI-WERLE L, HUNT TE, HENG-MOSS TM \& LOUIS J. 2018. Abscisic and jasmonic acids contribute to soybean tolerance to the soybean aphid (Aphis glycines Matsumura). Sci Rep 8: 15148.

CHEN MS. 2008. Inducible direct plant defense against insect herbivores: A review. Insect Sci 15: 101-114.

CHOUGULE NP \& BONNING BC. 2012. Toxins for transgenic resistance to hemipteran pests. Toxins 4: 405-429.

DONOVAN MP, NABITY PD \& DELUCIA EH. 2013. Salicylic acidmediated reductions in yield in Nicotiana attenuata challenged by aphid herbivory. Arthrop-Plant Interact 7: 45-52.

ERLANGER BF, KOKOWSKY N \& COHEN W. 1961. The preparation and properties of two new chromogenic substrates of trypsin. Arch Biochem Biophys 95: 271-278.

FARMER EE \& RYAN CA. 1992. Octadecanoid precursors of jasmonic acid activate the synthesis of wound-inducible proteinase inhibitors. Plant Cell 4: 129-134.

FELTON GW, CHUNG SH, HERNANDEZ MGE, LOUIS J, PEIFFER M \& TIAN D. 2014. Herbivore oral secretions are the first line of protection against plant-induced defences. Annu Plant Rev 47: 37-76.
FIORENTINO A, D'ABROSCA B, PACÍFICO S, GOLINO A, MASTELLONE C, ORIANO P \& MONACO P. 2007. Reactive oxygen species scavenging activity of flavone glycosides from Melilotus neapolitana. Molecules 12: 263-270.

GIORDANENGO P, BRUNISSEN L, RUSTERUCCI C, VINCENT C, VAN BEL A, DINANT S, GIROUSSE C, FAUCHER M \& BONNEMAIN JL. 2010. Compatible plant-aphid interactions: how aphids manipulate plant responses. Comptes Rendus Biol 333: 516-523.

HOYSTED GA, LILLEY CJ, FIELD KJ, DICKINSON M, HARTLEY SE \& URWIN PE. 2017. A plant-feeding nematode indirectly increases the fitness of an aphid. Front Plant Sci 8: 1897.

JOSHI RS, GUPTA VS \& GIRI AP. 2014. Differential antibiosis against Helicoverpa armigera exerted by distinct inhibitory repeat domains of Capsicum annuum proteinase inhibitors. Phytochem 101: 16-22.

KAKADE ML, RACKIS JJ, MCGHEE JE \& PUSKI G. 1974. Determination of trypsin inhibitor activity of soy products: a collaborative analysis of an improved procedure. Cereal Chem 51: 376-382.

KANNO H, HASEGAWA M \& KODAMA O. 2012. Accumulation of salicylic acid, jasmonic acid and phytoalexins in rice, Oryza sativa, infested by the white-backed planthopper, Sogatella furcifera (Hemiptera: Delphacidae). App Entomol Zool 47: 27-34.

LEITE MV, AUAD AM, RESENDE TT, FRIAS MP, FONSECA MG \& CASTRO RJC. 2014. Do salicylic acid, nitric oxide and feeding by Mahanarva spectabilis nymphs induce a resistance response in elephant grass? Exp Agric 50: 498-504.

LOSVIK A, BESTE L, GLINWOOD R, IVARSON E, STEPHENS J, ZHU LH, JONSSON L. 2017a. Overexpression and down-regulation of barley lipoxygenase LOX2.2 affects jasmonate-regulated genes and aphid fecundity. Int J Mol Sci 18: 2765.

LOSVIK A, BESTE L, MEHRABI S \& JONSSON L. 2017b. The protease inhibitor CI2C gene induced by bird cherry-oat aphid in barley inhibits green peach aphid fecundity in transgenic Arabidopsis. Int J Mol Sci 18: 1317.

MACHADO JC, MARTINS CE, AUAD AM, ROCHA WSD, LÉDO FJS, PEREIRA AV, SOUZA SOBRINHO F \& BENITES FRG. 2012. Banco ativo de germoplasma de capim-elefante: avaliação da resistência a cigarrinha das pastagens e tolerância à toxidez por alumínio. Documentos 159: Embrapa Gado de Leite, 28 p.

MERIÑO-CABRERA Y, ZANUNCIO JC, SILVA RS, SOLIS-VARGAS M, CORDEIRO G, RAINHA FR, CAMPOS WG, PICANÇO MC \& OLIVEIRA MGA. 2018. Biochemical response between insects and plants: an investigation of enzyme activity in the digestive system of Leucoptera coffeella (Lepidoptera: 
Lyonetiidae) and leaves of Coffea arabica (Rubiaceae) after herbivory. Ann Appl Biol 172: 236-243.

MILES JW, CARDONA C \& SOTELO G. 2006. Recurrent selection in a synthetic brachiariagrass population improves resistance to three spittlebug species. Crop Sci 46: 1088-1093.

MÜLLER M \& MUNNÉ-BOSCH S. 2011. Rapid and sensitive hormonal profiling of complex plant samples by liquid chromatography coupled to electrospray ionization tandem mass spectrometry. Plant Methods 7: 37.

NGUYEN D, RIEU I, MARIANI C \& VAN DAM NM. 2016. How plants handle multiple stresses: hormonal interactions underlying responses to abiotic stress and insect herbivory. Plant Mol Biol 91: 727-740.

O'BRIEN JA, DAUDI A, BUTT VS \& BOLWELL GP. 2012. Reactive oxygen species and their role in plant defence and cell wall metabolism. Planta 236: 765-779.

OLIVEIRA CFR, SOUZA TP, PARRA JRP, MARANGONI S, SILVAFILHO MC \& MACEDO MLR. 2013. Insensitive trypsins are differentially transcribed during Spodoptera frugiperda adaptation against plant protease inhibitors. Comp Biochem Physiol 165: 19-25.

OLIVEIRA MGA, DE SIMONE SG, XAVIER LP \& GUEDES RNC. 2005. Partial purification and characterization of digestive trypsin-like proteases from the velvet bean caterpillar, Anticarsia gemmatalis. Comp Biochem Physiol 140: 369-380.

PAIXÃO GP, LOURENÇÃO AL, SILVA CR, CORDEIRO G, BARROS RA, OLIVEIRA JA, VISÔTTO LE \& OLIVEIRA MGA. 2016. Active response of soybean to defoliator Anticarsia gemmatalis Hübner: strategies to overcome protease inhibitor production. Idesia 34: 69-75.

PAIXÃO GP, LOURENÇÃO AL, SILVA CR, MENDONÇA EG, SILVA PL, OLIVEIRA JA, ZANUNCIO JC \& OLIVEIRA MGA. 2013. Biochemical responses of Anticarsia gemmatalis (Lepidoptera: Noctuidae) in soybean cultivars sprayed with the protease inhibitor berenil. J Agric Food Chem 61: 8034-8038.

PEREIRA JF ET AL. 2018. Research priorities for nextgeneration breeding of tropical forages in Brazil. Crop Breed Appl Biotechnol 18: 314-319.

RESENDE TT, AUAD AM, FONSECA MDG, SOUZA SOBRINHO F, SANTOS DR \& SILVA SEB. 2013. The damage capacity of Mahanarva spectabilis (Distant, 1909) (Hemiptera: Cercopidae) adults on Brachiaria ruziziensis pasture. The Sci W J 2013: 281295.

ROACH T, COLVILLE L, BECKETT RP, MINIBAYEVA FV, HAVAUX M \& KRANNER I. 2015. A proposed interplay between peroxidase, amine oxidase and lipoxygenase in the wounding-induced oxidative burst in Pisum sativum seedlings. Phytochem 112: 130-138.

SCHUMAN MC \& BALDWIN IT. 2016. The layers of plant responses to insect herbivores. Annu Rev Entomol 61: 373-394.

SHIVAJI R, CAMAS A, ANKALA A, ENGELBERTH J, TUMLINSON JH, WILLIAMS WP, WILKINSON JR \& LUTHE DS. 2010. Plants on constant alert: elevated levels of jasmonic acid and jasmonate-induced transcripts in caterpillar-resistant maize. J Chem Ecol 36: 179-191.

SILVA SEB, AUAD AM, MORAES IC, ALVARENGA R, CLAUDINO SS \& RESENDE TT. 2017. Biological Performance and preference of Mahanarva spectabilis (Hemiptera: Cercopidae) for feeding on different forage plants. J Econ Entomol 110: 1877-1885.

SINGH S, SINGH A, KUMAR S, MITTAL P \& SINGH IK. 2020. Protease inhibitors: recent advancement in its usage as a potential biocontrol agent for insect pest management. Insect Sci 27(2): 186-201.

SMITH CM \& BOYKO EV. 2007. The molecular bases of plant resistance and defense responses to aphid feeding: current status. Entomol Exp Appl 122: 1-16.

SOUZA JC, SILVA RA, REIS PR, QUEIROZ DS \& SILVA DB. 2008. Cigarrinhas-das-pastagens: histórico, bioecologia, prejuízos, monitoramento e medidas de controle. Circular técnica 42: Epamig, 8 p.

STRASSBURG BBN, LATAWIEC AE, BARIONI LG, NOBRE CA, DA SILVA VP, VALENTIM JF, VIANNA M \& ASSAD ED. 2014. When enough should be enough: Improving the use of current agricultural lands could meet production demands and spare natural habitats in Brazil. Glob Environ Chang 28: 84-97.

TIMBÓ RV, HERMES-LIMA M, SILVA LP, MEHTA A, MORAES MCB \& PAULA DP. 2014. Biochemical aspects of the soybean response to herbivory injury by the brown stink bug Euschistus heros (Hemiptera: Pentatomidae). PLoS ONE 9: 10-35.

TOMARELLI RM. 1949. The use of azocasein as a substrate in the colorimetric determination of peptic and tryptic activity. J Lab Clin Med 34: 428-433.

VALÉRIO JR, CARDONA C, PECK DC \& SOTELO G. 2001. SpittlebugS: Bioecology, host plant resistance and advances in IPM. Proceedings of the $19^{\text {th }}$ International Grassland Congress. São Pedro, SP: Fundação de Estudos Agrários Luiz de Queiroz (FEALQ), p. 217-221.

VOELCKEL C, WEISSER WW \& BALDWIN IT. 2004. An analysis of plant-aphid interactions by different microarray hybridization strategies. Mol Ecol 13: 3187-3195.

WAR AR, PAULRAJ MG, AHMAD T, BUHROO AA, HUSSAIN B, IGNACIMUTHU S \& SHARMA HC. 2012. Mechanisms of plant 
defense against insect herbivores. Plant Signal Behav 7: $1306-1320$.

WAR AR, PAULRAJ MG, HUSSAIN B, BUHROO AA, IGNACIMUTHU S \& SHARMA HC. 2013. Effect of plant secondary metabolites on legume pod borer, Helicoverpa armigera. J Pest Sci 86: 399-408.

WASTERNACK C \& HAUSE B. 2013. Jasmonates: biosynthesis, perception, signal transduction and action in plant stress response, growth and development. An update to the 2007 review in Annals of Botany. Ann Bot 111: 1021-1058.

WHALON ME, MOTA-SANCHEZ D, HOLLINGWORTH RM \& DUYNSLAGER L. 2019. Arthropod pesticide resistance data base 2019. http://www.pesticideresistance.com/ (accessed 04 July 2019).

YAN L ET AL. 2013. Role of tomato lipoxygenase D in woundinduced jasmonate biosynthesis and plant immunity to insect herbivores. PLoS Gen 9: e1003964.

ZHOU G, REN N, QI J, LU J, XIANG C, JU H, CHENG J \& LOU Y. 2014. The 9-lipoxygenase Osr9-LOX1 interacts with the 13-lipoxygenase-mediated pathway to regulate resistance to chewing and piercing-sucking herbivores in rice. Physiol Plant 152: 59-69.

\section{SUPPLEMENTARY MATERIAL}

\section{Table SI.}

\section{How to cite}

BARROS RA, VITAL CE, JÚNIOR NRS, VARGAS MAS, MONTEIRO LP, FAUSTINO VA, AUAD AM, PEREIRA JF, DE OLIVEIRA EE, RAMOS HJO \& OLIVEIRA MGA. 2021. Differential defense responses of tropical grasses to Mahanarva spectabilis (Hemiptera: Cercopidae) infestation. An Acad Bras Cienc 93: e20191456. DOI 10.1590/0001-3765202120191456.

Manuscript received on November 26, 2019;

accepted for publication on May 16, 2020

RAFAEL DE A. BARROS ${ }^{1}$

https://orcid.org/0000-0003-2369-4538

CAMILO E. VITAL ${ }^{1}$

https://orcid.org/0000-0002-2567-9780

NEILIER R.S. JÚNIOR ${ }^{1}$

https://orcid.org/0000-0002-4683-249X

MANUEL A.S. VARGAS ${ }^{2}$

https://orcid.org/0000-0003-0046-9995

LUANA P. MONTEIRO 1

https://orcid.org/0000-0002-6270-0067

\section{VERÔNICA A. FAUSTINO ${ }^{1}$}

https://orcid.org/0000-0001-7322-0918

\section{ALEXANDER M. AUAD}

https://orcid.org/0000-0002-3420-201X

\section{JORGE F. PEREIRA ${ }^{3}$}

https://orcid.org/0000-0001-9340-065X

\section{EUGÊNIO E. DE OLIVEIRA ${ }^{2}$}

https://orcid.org/0000-0003-1174-6564

\section{HUMBERTO J.O. RAMOS ${ }^{1}$}

https://orcid.org/0000-0001-6447-8108

MARIA GORETI DE A. OLIVEIRA ${ }^{1}$

https://orcid.org/0000-0001-5603-9471

${ }^{1}$ Universidade Federal de Viçosa (UFV), Laboratório de Enzimologia e Bioquímica de Proteínas e Peptídeos, Departamento de Bioquímica e Biologia Molecular, BIOAGRO/INCT-IPP, Av. Peter Henry Rolfs, s/n, Campus Universitário, 36570-900 Viçosa, MG, Brazil

${ }^{2}$ Universidade Federal de Viçosa (UFV), Departamento de Entomologia/BIOAGRO, Av. Peter Henry Rolfs, s/n, Campus Universitário, 36570-900 Viçosa, MG, Brazil

${ }^{3}$ Embrapa Gado de Leite, Dom Bosco, 610, Aeroporto, 36038-330 Juiz de Fora, MG, Brazil

Correspondence to: Humberto Josué de Oliveira Ramos E-mail: humramos.ufv.br@gmail.com

\section{Author contributions}

Rafael de A. Barros: investigation (equal); writing original draft (equal) \& editing (lead). Camilo E. Vital: methodology (equal); writing review \& editing (equal). Neilier R. da Silva Júnior: writing review \& editing (lead). Manuel A.S. Vargas: validation (equal); methodology (equal). Luana P. Monteiro: methodology (equal). Verônica A. Faustino: editing (equal). Jorge F. Pereira, Alexander M. Auad and Humberto J.O. Ramos: supervision (equal); writing review \& editing (equal). Eugênio E. de Oliveira: writing review \& editing (equal). Maria Goreti de A. Oliveira: funding acquisition (equal); project administration (equal); resources (equal); writing review \& editing (equal).

\section{(cc) BY}

